\title{
Measurement of Nutritive Value and Phenolic Compounds in Forage Plants Used in Animal Production
}

\author{
Fabíola Fonseca Lage ${ }^{1}$, Meryene de Carvalho Teixeira ${ }^{1}$, Augusto Ramalho de Morais ${ }^{2}$, \\ Antonio Ricardo Evangelista ${ }^{3}$, Antônio Augusto Rocha Athayde ${ }^{4}$, Maria das Graças Cardoso ${ }^{1}$ \\ \& Adelir Aparecida Saczk ${ }^{1}$ \\ ${ }^{1}$ Departamento de Química, Universidade Federal de Lavras, Lavras, MG, Brazil \\ ${ }^{2}$ Departamento de Estatística, Universidade Federal de Lavras, Lavras, MG, Brazil \\ ${ }^{3}$ Departamento de Zootecnia, Universidade Federal dos Vales do Jequitinhonha e Mucuri, Diamantina, MG, \\ Brazil \\ ${ }^{4}$ Instituto Federal Minas Gerais, Bambui, MG, Brazil \\ Correspondence: Adelir Aparecida Saczk, Department of Chemistry, Federal University of Lavras, Lavras, MG, \\ Brazil. E-mail: adelir@ufla.br
}

Received: October 26, 2019

Accepted: January 10, $2020 \quad$ Online Published: October 15, 2020

doi:10.5539/jas.v12n11p209

URL: https://doi.org/10.5539/jas.v12n11p209

\begin{abstract}
Secondary metabolites are important organic metabolites produced by plants. These metabolites include phenolic compounds, which have been of research interest because phenolics are considered an antinutritional factor for ruminants, compromise the bioavailability of nutrients. This study included a chemical composition analysis, an analysis of the condensed tannin content and the identification and quantification of the phenolic compounds present in the following plants cultivated with and without fertilisation: Coastcross- 1 grass $(G)$ and the legumes Stylosanthes guianensis cv. Mineirão (MS), Stylosanthes capitata $\times$ Stylosanthes macrocephala $\mathrm{cv}$. Campo Grande (CGS), Arachis pintoi cv. Amarillo (AA) and Arachis pintoi cv. Belmonte (AB). High-performance liquid chromatography (HPLC) was used to analyse 13 phenolic compounds. The forage with the best nutritive value was Amarillo pinto peanut. The condensed tannin content was higher in the legumes than that in the grass. Vanillin and o-coumaric, m-coumaric, caffeic and ferulic acid were detected in all the cultivars. The cultivar with the largest variety of phenolic compounds was Coastcross-1 grass. Diversity existed in the occurrence of phenolic compounds, which indicated the presence of condensed tannins in the cultivars and possibly that the diversity does not affect the concentration of these compounds. The AA cultivar was the most interesting alternative for the establishment of pasture intercropped with Coastcross-1 grass.
\end{abstract}

Keywords: Arachis pintoi, Coastcross-1, HPLC, phenolic content, Stylosanthes guianensis, Tannins

\section{Introduction}

Plants produce a considerable quantity of organic metabolites; these substances are divided into primary metabolites, with structural, plastic and energy storage functions, and secondary metabolites, whose function is to defend against herbivores and pathogens, to attract pollinators and to act as agents of competition between plants and of symbiosis between plants and microorganisms. Secondary compounds can also be used as antimicrobials in cosmetics, food and agrochemicals (Thorat, 2018).

Secondary metabolites include phenolic compounds (flavonoids, lignins and tannins), terpenes (essential oils, saponins, carotenes and xanthophylls) and alkaloids (caffeine) and may vary in quantity according to species, physiological stage and edaphic and climatic conditions. These compounds are of scientific interest due to their antioxidant, physiological and nutritional properties (Thorat, 2018).

The phenolic secondary metabolites are known as antinutritional factors because of their direct relationship with intake restriction and forage digestion and their influence on animal acceptability and animal performance. The phenolic compounds compose the phenol group and contain an aromatic ring bonded to a functional hydroxyl group; the most important phenolic compounds are lignin and tannin (Edvan \& Bezerra, 2018). 
Lignin is a polymer whose function is to provide plant tissues with rigidity, impermeability and resistance to microbiological and mechanical attacks. Lignin is important to consider when establishing pastures because this polymer is the chemical component of fibre that is most frequently linked to nutrient indigestibility. Lignin has been used to predict the nutritive value of forage plants. Generally, lignin contains three types of aromatic alcohol subunits: coniferyl alcohol, which is predominant in tree species, and sinapyl alcohol and $p$-coumaryl alcohol, which are predominant in grasses and legumes (Figueiredo et al., 2019).

Tannins are high-molecular-weight (500 to $3000 \mathrm{Da}$ ) polyphenol complexes that differ from other polyphenols in their ability to precipitate proteins, metal ions, amino acids and polysaccharides. The tannins are divided into hydrolysable tannins, which produce carbohydrates and phenolic acids after hydrolysis, and condensed tannins, which are resistant to hydrolysis. Their amount varies with the plant species but can also vary within the same species. According to their concentration in forage, tannins may have beneficial effects on animal metabolism, such as an increase in amino acid uptake and a reduction in the intestinal parasite population and may produce an increase in microbial protein synthesis and a reduction in ruminal methane production (Naumann et al., 2017).

Knowing the phenolic profile of dietary roughage may help the formulation of diets that improve feed utilisation by ruminants. However, many researchers do not include the evaluation of phenolic compounds in their work; as a result, little is known regarding the nature of these compounds in tropical forages.

In this context, the objective of the present study was to determine the nutritive value of forage plants in the Cynodon, Arachis and Stylosanthes genera and to identify and quantify their phenolic compounds in three harvest seasons, with monocropping or intercropping and with or without fertilisers.

\section{Materials and Methods}

\subsection{Reagents}

Ultrapure water purified with the Millipore Milli-Q system (Milli-Q ${ }^{\circledR}$ Corporation, Bedford, USA) $(\rho=18.2 \mathrm{M} \Omega$ ) was used at room temperature. Acetic acid and high-performance liquid chromatography (HPLC) grade methanol (Merck, Darmstadt, Germany) were used to prepare the mobile phase. HPLC grade caffeic, $p$-coumaric, gallic, ellagic and ferulic phenolic acids; catechin, epicatechin, gallocatechin and epigallocatechin gallate tannins; and quercetin and vanillin flavonoids were purchased from Sigma-Aldrich (St. Louis, MO, USA). $m$-Coumaric and $o$-coumaric acids were purchased from Fluka (St. Louis, MO, USA). Stock solutions were prepared in dimethyl sulfoxide and/or methanol (Merck).

\subsection{Implementation of the Experiment and Data Collection}

The experiment was implemented on the "Sitio Cata Vento" farm, located in Itutinga, MG, Brazil, under an intercropping system that predicted $30 \%$ legumes in the total forage produced. The following forages were used in the experiment: Coastcross-1 grass (Cynodon nlemfuensis Vanderyst $\times$ Cynodon dactylon L. Pers.) and the legumes Mineirão stylo (Stylosanthes guianensis (Aubl.) cv. Mineirão), Campo Grande stylo (Stylosanthes capitata $\mathrm{x}$ Stylosanthes macrocephala cv. Campo Grande) and pinto peanut (Arachis pintoi Krapov. \& WC Greg.) of the Belmonte and Amarillo cultivars.

Samples of Coastcross-1 grass (G) grown as a monocrop and intercropped with Mineirão stylo (G+MS), Campo Grande stylo $(\mathrm{G}+\mathrm{CGS})$ or pinto peanut of the Belmonte $(\mathrm{G}+\mathrm{AB})$ and Amarillo $(\mathrm{G}+\mathrm{AA})$ cultivars were evaluated.

One month prior to planting the monocrop, the soil phosphorus (P) content was corrected by applying a $54 \mathrm{~kg} \mathrm{ha}{ }^{1}$ dose of phosphorus pentoxide $\left(\mathrm{P}_{2} \mathrm{O}_{5}\right)$ in the form of superphosphate to the planting furrows, which were spaced 0.4 $\mathrm{m}$ apart. The forages were cultivated in $17.5 \mathrm{~m}^{2}$ lots, in which planting lines were spaced $0.7 \mathrm{~m}$ apart. At planting, in the treatments with fertilisation, $20 \mathrm{~kg}$ of nitrogen $(\mathrm{N}), 70 \mathrm{~kg}$ of $\mathrm{P}_{2} \mathrm{O}_{5}$ and $40 \mathrm{~kg}$ of potassium oxide $\left(\mathrm{K}_{2} \mathrm{O}\right)$ were applied per hectare by means of the 8-28-16 + $\mathrm{Zn}$ formulation, to meet the nutritional requirements and not limit the introduction of legumes. Three harvest periods occurred (January, April and December), with the plants being cut close to the ground when their height reached $30 \mathrm{~cm}$.

\subsection{Chemical Composition Analyses}

The samples collected in the three harvests were placed in paper bags, duly identified, sent to the Animal Research Laboratory of the Department of Animal Science (UFLA) and dried in a forced-air oven at $65^{\circ} \mathrm{C}$ until they reached constant weight. Subsequently, the samples were ground in Wiley mills with a $1 \mathrm{~mm}$ sieve and stored in plastic containers.

The dry matter (DM) and crude protein (CP) contents were determined according to AOAC (2005), calcium (Ca) and $\mathrm{P}$ were determined following the methodology proposed by Malavolta (1989), and neutral detergent fibre 
(NDF) and acid detergent fibre (ADF) were determined by the fibre partitioning method (Van Soest, Robertson \& Lewis, 1991).

\subsection{Determination of Condensed Tannins}

The content of condensed tannins was determined by the vanillin method (Agostini-Costa, A. Lima \& M. V. Lima, 2003). Tannin extraction was performed with $1.0 \mathrm{~g}$ of forage in $10.0 \mathrm{~mL}$ of $70 \%$ acetone. This mixture was vortexed for $3 \mathrm{~min}$, left standing for 1 hour and then vortexed again. This process was repeated twice. Subsequently, the extract was centrifuged for $15 \mathrm{~min}$ and filtered on glass wool before its absorbance was read at a wavelength of $500 \mathrm{~nm}$ based on a vanillin standard curve.

\subsection{Determination of Phenolic Compounds}

The lignin content (LIG) was determined in the Plant Research Laboratory, Department of Food Engineering (UFLA) by ADF analysis using the method described by Van Soest (1994).

Extractions of phenolic acids, tannins and flavonoids from forage plants were performed according to the modified version of Terril et al. (1990), in which $1.0 \mathrm{~g}$ of dried and milled sample was transferred to threaded centrifuge tubes, to which $10 \mathrm{~mL}$ of acetone/water solution $(70 / 30 \mathrm{v} / \mathrm{v})$ was added. The samples were shaken in a Certomat MO II orbital shaker (Schwarzenberg, Germany) at $100 \mathrm{rpm}$ for $30 \mathrm{~min}$ at room temperature. Then, the samples were centrifuged for $15 \mathrm{~min}$ at $4500 \mathrm{rpm}$, and the supernatant was filtered through glass wool and washed with approximately $10.0 \mathrm{~mL}$ of petroleum ether, to remove the fats. The extract was placed in glass containers wrapped in foil and stored at $4{ }^{\circ} \mathrm{C}$ to avoid the degradation of phenolic compounds.

For the HPLC analysis, a Shimadzu LC20-AD (Kyoto, Japan) equipped with a binary high-pressure pump (LC-20AD model), an automatic injector with autosampler (SIL-M20A model), an oven (CTO-20AC model) and a diode array detector (DAD, SPD-M20A model) was used. The detection was performed at a wavelength of $280 \mathrm{~nm}$. Samples and standards were injected into a Shimadzu Shim-pack C18 column $(250 \times 4.6 \mathrm{~mm}, 5 \mu \mathrm{m})$, connected to a Shimadzu pre-column $(5.0 \mathrm{~cm} \times 4.0 \mathrm{~mm}, 5 \mu \mathrm{m})$. The mobile phase was composed of the following solutions: $2 \%$ acetic acid (A) and methanol/water/acetic acid $(65 / 33 / 2 \mathrm{v} / \mathrm{v} / \mathrm{v})(\mathrm{B})$. The analyses were performed for a total time of $60 \mathrm{~min}$ at a temperature of $15{ }^{\circ} \mathrm{C}$ in a gradient system. Separation was performed using the following elution gradient: $100 \%$ solvent A for $25 \mathrm{~min}, 60 \%$ solvent A for $18 \mathrm{~min}, 55 \%$ solvent A for $7 \mathrm{~min}$ and $0 \%$ solvent A for 10 min. At the end of the run, solvent A was increased to $100 \%$ to equilibrate the column. The flow used in all the analyses was $1.25 \mathrm{~mL} \mathrm{~min}^{-1}$, and the injection volume was $20 \mu \mathrm{L}$. All the standard solutions and samples were filtered on Millipore membranes $(0.45 \mu \mathrm{m})$.

The identification of the phenolic compounds present in the plant extracts was established by comparison with the retention times of standard phenolic compounds, and their quantification was performed via the limits of detection (LODs) (3:1 signal to noise ratio) (Ribani et al., 2004; Aquino et al., 2006). Standard stock solutions were diluted in the concentration range of 0.05 to $42.48 \mathrm{mg} \mathrm{L}^{-1}$, and analytical curves were constructed by plotting the mean (n $=3$ ) detector response (peak area) as a function of the concentration of the phenolic compounds. The regularity of the data set was determined by the standard deviation.

The accuracy of the method was evaluated by determining the reproducibility, which involved three consecutive injections of the standard for each compound via the same method performed under similar conditions within a short interval (Ribani et al., 2004). The recovery of each phenolic constituent was estimated by adding a known concentration of standard to a forage sample and determining the increase in concentration according to the increase in peak area.

The method was validated based on the parameters of linearity, precision (repeatability), accuracy (recovery), LODs and quantification and selectivity (IUPAC, 1997).

\subsection{Statistical Design}

A randomised block design with three replications was used. The treatments were arranged in a split-plot scheme, and draws were used to determine the fertilisation (absence and presence) of each plot, the forages of the subplots and the harvests $\left(1^{\text {st }}, 2^{\text {nd }}\right.$ and $\left.3^{\text {rd }}\right)$ of the sub-subplots. Statistical analyses were performed using the SAS (Statistical Analysis System, version 9.2) programme.

\section{Results and Discussion}

\subsection{Nutritive Value}

An important parameter used in forage evaluation is DM. Chemical changes and tissue degradation during storage are avoided by drying the plant material. DM is also important when estimating the quantity of nutrients that animals consume (Soeste, 2018). In the present study, the results for the DM analysis of G were not significantly 
different ( $p>0.05$ ) among the harvests or because of fertilisation. The intercropping also did not increase the DM content of the grasses, demonstrating that the legume did not interfere with grass development during the experiment.

The legumes showed an increase in DM content from the second to the third harvest. The CGS cultivar showed the highest DM content (46.88\%) in relation to the others. These results relate to the physiological maturation of the forages.

The $\mathrm{Ca}$ and $\mathrm{P}$ contents for $\mathrm{G}$ monocropped and grown in $\mathrm{G}+\mathrm{MS}, \mathrm{G}+\mathrm{CGS}, \mathrm{G}+\mathrm{AB}$ and $\mathrm{G}+\mathrm{AA}$ intercrops are presented in Table 1.

Table 1. Mean values of $\mathrm{P}$ and Ca contents, corrected for $100 \%$ DM, of G monocropped and intercropped with legumes

\begin{tabular}{|c|c|c|c|c|c|c|c|c|c|}
\hline \multirow{3}{*}{ Grass } & \multicolumn{6}{|c|}{ Values of $\mathrm{P}(\%)$} & \multicolumn{3}{|c|}{ Values of Ca (\%) } \\
\hline & \multicolumn{2}{|c|}{$1^{\text {st }}$ harvest } & \multicolumn{2}{|c|}{$2^{\text {nd }}$ harvest } & \multicolumn{2}{|c|}{$3^{\text {rd }}$ harvest } & \multirow{2}{*}{$1^{\text {st }}$ harvest } & \multirow{2}{*}{$2^{\text {nd }}$ harvest } & \multirow{2}{*}{$3^{\text {rd }}$ harvest } \\
\hline & $\mathrm{A}^{\mathrm{f}}$ & $\mathrm{NA}^{\mathrm{g}}$ & A & NA & A & NA & & & \\
\hline $\mathrm{G}^{\mathrm{a}}$ & $0.13 b c \mathrm{~A}$ & $0.10 \mathrm{bcA}$ & $0.15 \mathrm{abA}$ & $0.12 \mathrm{abc} \mathrm{B}$ & $011 \mathrm{bA}$ & $0.10 \mathrm{baA}$ & $0.35 \mathrm{a}$ & $0.50 \mathrm{a}$ & $0.33 \mathrm{a}$ \\
\hline $\mathrm{G}+\mathrm{CGS}^{\mathrm{b}}$ & $0.14 \mathrm{abc} \mathrm{A}$ & $0.09 \mathrm{bcB}$ & $0.15 \mathrm{abA}$ & $0.10 \mathrm{c} \mathrm{B}$ & $0.10 \mathrm{bA}$ & $0.08 \mathrm{bA}$ & $0.36 \mathrm{a}$ & $0.60 \mathrm{a}$ & $0.36 \mathrm{a}$ \\
\hline $\mathrm{G}+\mathrm{MS}^{\mathrm{c}}$ & $0.17 \mathrm{abcA}$ & $0.10 \mathrm{bcB}$ & $0.17 \mathrm{abA}$ & $0.10 \mathrm{c} \mathrm{B}$ & $0.10 \mathrm{bA}$ & $0.09 \mathrm{bA}$ & $0.41 \mathrm{a}$ & $0.53 \mathrm{a}$ & $0.31 \mathrm{a}$ \\
\hline $\mathrm{G}+\mathrm{AB}^{\mathrm{d}}$ & $0.12 \mathrm{c} \mathrm{A}$ & $0.11 \mathrm{bcA}$ & $0.14 \mathrm{~b} \mathrm{~A}$ & $0.11 \mathrm{bcB}$ & $0.10 \mathrm{bA}$ & $0.08 \mathrm{bA}$ & $0.34 \mathrm{a}$ & $0.48 \mathrm{a}$ & $0.27 \mathrm{a}$ \\
\hline $\mathrm{G}+\mathrm{AA}^{\mathrm{e}}$ & $0.15 \mathrm{abc} \mathrm{A}$ & $0.09 \mathrm{bcB}$ & $0.16 \mathrm{a} \mathrm{A}$ & $0.13 \mathrm{abcA}$ & $0.10 \mathrm{bA}$ & $0.08 \mathrm{bA}$ & $0.32 b$ & $0.82 \mathrm{a}$ & $0.32 b$ \\
\hline
\end{tabular}

Note. $\mathrm{G}^{\mathrm{a}}=$ monocropped grass, $\mathrm{G}+\mathrm{CGS}^{\mathrm{b}}=$ grass intercropped with Campo Grande stylo, $\mathrm{G}+\mathrm{MS}^{\mathrm{c}}=$ grass intercropped with Mineirão stylo, $G+A^{d}=$ grass intercropped with Belmonte pinto peanut, $G+A^{e}=$ grass intercropped with Amarillo pinto peanut, $\mathrm{A}^{\mathrm{f}}=$ fertilised cultivar, and $\mathrm{NA}^{\mathrm{g}}=$ non-fertilised cultivar. Means followed by the same lowercase letter do not differ at the 5\% probability level according to the Tukey test, which compares the forages among the first, second and third harvests. Means followed by the same capital letter do not differ at the 5\% probability level according to the Tukey test, which compares the fertilisations within each harvest.

The $\mathrm{P}$ contents ranged from 0.08 to $0.17 \%$, with the $\mathrm{P}$ requirement ranging from 0.12 to $0.15 \%$ depending on the weight gain for cattle. For the fertilised species, no significant difference in the $\mathrm{P}$ content occurred among the harvests (Table 1). This observation may indicate that the supply of $\mathrm{P}$ to cattle occurs constantly throughout the year. In addition, no significant difference in the $\mathrm{P}$ content existed between the monocropped and intercropped grass of the same harvest. However, the concentrations of P did vary among the harvests and the intercrop treatments when analysing the non-fertilised species. The use of legumes (green fertilisers) in the system improves the soil quality due to faster nutrient cycling, thereby favouring utilisation by the intercropped plants. Especially favoured is the utilisation of elements with leaching potential, such as $\mathrm{N}$ and exchangeable cations, or those that can be retained with relative ease, such as $\mathrm{P}$ in weathered soils. In addition, the presence of atmospheric $\mathrm{N}$-fixing bacteria and mycorrhizal fungal hyphae interacts with the soil to improve nutrient availability and uptake by forages (Klabil et al., 2015). In the first and second harvests, a significant difference $(p<0.05)$ existed with respect to fertilisation, indicating that the fertilisation affected nutrient availability to the plant.

The Ca content ranged from 0.27 to $0.82 \%$, with the Ca requirement ranging from 0.19 to $0.27 \%$ depending on the weight gain for cattle. The Ca content analysis of the cultivars indicated no significant effect $(p<0.05)$ among the harvest seasons and levels between the monocropped and intercropped grasses (Table 1), with no statistically significant effect of fertilisation.

Table 2 shows the $\mathrm{P}$ and $\mathrm{Ca}$ contents of the leguminous plants intercropped with the grass. 
Table 2. Mean values of $\mathrm{P}$ and Ca contents, corrected for $100 \% \mathrm{DM}$, of legumes intercropped with grass

\begin{tabular}{|c|c|c|c|c|c|c|c|c|c|}
\hline \multirow{3}{*}{ Leguminous } & \multicolumn{6}{|c|}{ Values of $\mathrm{P}(\%)$} & \multicolumn{3}{|c|}{ Values of Ca (\%) } \\
\hline & \multicolumn{2}{|c|}{$1^{\text {st }}$ harvest } & \multicolumn{2}{|c|}{$2^{\text {nd }}$ harvest } & \multicolumn{2}{|c|}{$3^{\text {rd }}$ harvest } & \multirow{2}{*}{$1^{\text {st }}$ harvest } & \multirow{2}{*}{$2^{\text {nd }}$ harvest } & \multirow{2}{*}{$3^{\text {rd }}$ harvest } \\
\hline & $A^{e}$ & $\mathrm{NA}^{\mathrm{f}}$ & A & $\mathrm{NA}$ & A & NA & & & \\
\hline $\mathrm{CGS}^{\mathrm{a}}$ & $0.14 \mathrm{bcA}$ & $0.07 \mathrm{cB}$ & $0.13 \mathrm{bA}$ & $0.16 \mathrm{aA}$ & $0.10 \mathrm{bA}$ & $0.10 \mathrm{bA}$ & $1.28 \mathrm{ab}$ & $1.53 \mathrm{a}$ & $1.17 \mathrm{~b}$ \\
\hline $\mathrm{MS}^{\mathrm{b}}$ & $0.16 \mathrm{abcA}$ & $0.12 \mathrm{bcB}$ & $0.18 \mathrm{abA}$ & $0.12 \mathrm{abcB}$ & $0.10 \mathrm{bA}$ & $0.10 \mathrm{bA}$ & $1.46 \mathrm{ab}$ & $1.57 \mathrm{a}$ & $1.24 \mathrm{~b}$ \\
\hline $\mathrm{AB}^{\mathrm{c}}$ & $0.18 \mathrm{abA}$ & $0.14 \mathrm{abA}$ & $0.16 \mathrm{abA}$ & $0.14 \mathrm{abcA}$ & $0.13 \mathrm{bA}$ & $0.10 \mathrm{bB}$ & $1.25 \mathrm{~b}$ & $1.61 \mathrm{a}$ & $1.22 \mathrm{~b}$ \\
\hline $\mathrm{AA}^{\mathrm{d}}$ & $0.20 \mathrm{aA}$ & $0.19 \mathrm{aA}$ & $0.20 \mathrm{aA}$ & $0.16 \mathrm{abB}$ & $0.20 \mathrm{aA}$ & $0.20 \mathrm{aA}$ & $2.10 \mathrm{a}$ & $1.80 \mathrm{a}$ & $1.78 \mathrm{a}$ \\
\hline
\end{tabular}

Note. $\mathrm{CGS}^{\mathrm{a}}=$ Campo Grande stylo, $\mathrm{MS}^{\mathrm{b}}=$ Mineirão stylo, $\mathrm{AB}^{\mathrm{c}}=$ Belmonte pinto peanut, $\mathrm{AA}^{\mathrm{d}}=$ Amarillo pinto peanut, $\mathrm{A}^{\mathrm{e}}=$ fertilised cultivar, and $\mathrm{NA}^{\mathrm{f}}=$ non-fertilised cultivar. Means followed by the same lowercase letter do not differ at the $5 \%$ probability level according to the Tukey test, which compares the forages among the first, second and third harvests. Means followed by the same capital letter do not differ at the $5 \%$ probability level according to the Tukey test, which compares the fertilisations in each harvest.

No significant differences $(\mathrm{p}>0.05)$ were observed in the $\mathrm{P}$ content between the legume harvests (Table 2$)$. The cultivar with the highest $P$ content was AA. Fertilisation had an effect $(p<0.05)$ on the P content, and the fertilised forages $(p<0.05)$ had a higher $P$ content than that of the non-fertilised ones.

No significant effect $(\mathrm{p}<0.05)$ of fertilisation on the Ca content was detected, and Table 2 shows the overall mean and the interaction between the harvests.

In general, the harvest time influenced $(\mathrm{p}<0.05)$ the $\mathrm{Ca}$ content of the legumes (Table 2$)$.

When evaluating the A. pintoi yield established under different plant population arrangements in planosol, Machado et al. (2005) found average levels for P and K of 0.26 and $1.39 \%$, respectively.

The CP contents of grass in the G monocrop and in the G+MS, G+CGS, G+AB and G+AA intercrops are shown in Table 3.

Table 3. Mean CP content, corrected for 100\% DM, of monocropped grass and grass intercropped with legumes

\begin{tabular}{|c|c|c|c|c|c|c|}
\hline \multirow{3}{*}{ Grass } & \multicolumn{6}{|c|}{ Values of CP (\%) } \\
\hline & \multicolumn{2}{|c|}{$1^{\text {st }}$ harvest } & \multicolumn{2}{|c|}{$2^{\text {nd }}$ harvest } & \multicolumn{2}{|c|}{$3^{\text {rd }}$ harvest } \\
\hline & $\mathrm{A}$ & NA & $\mathrm{A}$ & NA & $\mathrm{A}$ & NA \\
\hline $\mathrm{G}^{\mathrm{a}}$ & $4.85 \mathrm{cB}$ & $6.23 \mathrm{cde} A$ & $4.63 \mathrm{cA}$ & $4.68 \mathrm{bA}$ & $5.42 \mathrm{cA}$ & $5.57 \mathrm{cA}$ \\
\hline $\mathrm{G}+\mathrm{CGS}^{\mathrm{b}}$ & $5.20 \mathrm{cA}$ & $4.48 \mathrm{eA}$ & $5.33 \mathrm{cA}$ & $5.02 \mathrm{bA}$ & $5.90 \mathrm{cA}$ & $5.48 \mathrm{cA}$ \\
\hline $\mathrm{G}+\mathrm{MS}^{\mathrm{c}}$ & $5.46 \mathrm{cB}$ & 7.93abcA & $4.69 \mathrm{cA}$ & $4.80 \mathrm{bA}$ & $5.83 \mathrm{cA}$ & $5.74 \mathrm{cA}$ \\
\hline $\mathrm{G}+\mathrm{AB}^{\mathrm{d}}$ & $4.40 \mathrm{cA}$ & $4.30 \mathrm{eA}$ & $4.34 \mathrm{cA}$ & $4.68 \mathrm{cA}$ & $5.90 \mathrm{cA}$ & $5.14 \mathrm{cA}$ \\
\hline $\mathrm{G}+\mathrm{AA}^{\mathrm{e}}$ & $4.73 \mathrm{cA}$ & $5.36 \mathrm{de} A$ & $4.66 \mathrm{cA}$ & $4.68 \mathrm{cA}$ & $5.90 \mathrm{cA}$ & $5.64 \mathrm{cA}$ \\
\hline
\end{tabular}

Note. See caption Table 1.

No significant difference in CP content occurred between mono- and intercropped G, possibly indicating that the legume presence did not affect the $\mathrm{CP}$ content of the grass. Furthermore, in most cases, no significant difference occurred between the fertilised and non-fertilised grasses, indicating that fertilisation does not affect the $\mathrm{CP}$ concentration (Table 3).

The CP levels were between 4.30 and $7.93 \%$. These values are below those observed in the literature (Aguirre et al., 2016; Olivo et al., 2016). The CP content of plants may be affected by factors such as soil fertilisation and liming. Insufficient $\mathrm{P}$ and $\mathrm{K}$ also lead to a reduction in $\mathrm{N}$ and to less $\mathrm{N}$ transformation into protein. A direct association exists between $\mathrm{P}$ and protein, with a deficiency in one aggravating a deficiency in the other.

Table 4 shows the $\mathrm{CP}$ values for the leguminous plants intercropped with the grass. 
Table 4. Mean values of CP, corrected for $100 \%$ DM, in legumes intercropped with grass

\begin{tabular}{|c|c|c|c|c|c|c|}
\hline \multirow{3}{*}{ Leguminous } & \multicolumn{6}{|c|}{ Values of CP (\%) } \\
\hline & \multicolumn{2}{|c|}{$1^{\text {st }}$ harvest } & \multicolumn{2}{|c|}{$2^{\text {nd }}$ harvest } & \multicolumn{2}{|c|}{$3^{\text {rd }}$ harvest } \\
\hline & $A^{f}$ & $\mathrm{NA}^{\mathrm{g}}$ & $\mathrm{A}$ & NA & $\mathrm{A}$ & NA \\
\hline $\mathrm{CGS}^{\mathrm{a}}$ & $8.30 \mathrm{bA}$ & $7.12 \mathrm{bcdA}$ & $9.46 \mathrm{bA}$ & $8.71 \mathrm{aA}$ & $9.70 \mathrm{bA}$ & $10.05 \mathrm{bA}$ \\
\hline $\mathrm{MS}^{\mathrm{b}}$ & $10.34 \mathrm{abA}$ & $8.87 \mathrm{abA}$ & $12.12 \mathrm{aA}$ & $10.65 \mathrm{aA}$ & $9.11 \mathrm{bA}$ & $10.35 \mathrm{bA}$ \\
\hline $\mathrm{AB}^{\mathrm{c}}$ & $8.58 \mathrm{bA}$ & $8.20 \mathrm{abcA}$ & $10.17 \mathrm{abA}$ & $10.43 \mathrm{aA}$ & $14.66 \mathrm{aA}$ & $12.73 \mathrm{aB}$ \\
\hline $\mathrm{AA}^{\mathrm{d}}$ & $11.90 \mathrm{aA}$ & $9.96 \mathrm{aB}$ & $11.60 \mathrm{abA}$ & $10.65 \mathrm{aA}$ & $13.04 \mathrm{aA}$ & $14.26 \mathrm{aA}$ \\
\hline
\end{tabular}

Note. See caption Table 2.

For the legumes, an increase generally occurred in the CP content as the plant aged, but the increase was not statistically significant. The AA cultivar showed the highest CP content. No effect $(p>0.05)$ of fertilisation on the $\mathrm{CP}$ content of the evaluated legumes was detected.

Protein-rich forages provide relatively nutritious diets and an increased carrying capacity of pasture and weight gain per hectare. The CP content of legumes exceeds that found in grasses. Thus, the intercropping of grass and legumes has been used to increase the productivity, profitability and sustainability of the cattle production system (Gulwa, Mgujulwa, \& Beyene, 2018). When analysing the chemical composition of ten varieties of S. guianensis, Li et al. (2014) found an average CP content of $10.5 \%$, a result similar to that found in the present study (Table 4). The limiting CP content for the adequate activity of rumen microorganisms is $7 \%$, a value surpassed by all the legumes studied.

\subsection{Fibre and Lignin Content}

The analyses were performed for mono- and intercropped G (Table 5). The results of the legume analyses for theintercropped cultivars are shown in Table 6.

Table 5. NDF, ADF and lignin (\%) contents of mono- and intercropped grass

\begin{tabular}{|c|c|c|c|c|c|c|c|c|c|}
\hline \multirow{2}{*}{ Grass } & \multicolumn{3}{|c|}{ Values of NDF } & \multicolumn{3}{|c|}{ Values of ADF } & \multicolumn{3}{|c|}{ Values of lignin (\%) } \\
\hline & $1^{\text {st }}$ harvest & $2^{\text {nd }}$ harvest & $3^{\text {rd }}$ harvest & $1^{\text {st }}$ harvest & $2^{\text {nd }}$ harvest & $3^{\text {rd }}$ harvest & $1^{\text {st }}$ harvest & $2^{\text {nd }}$ harvest & $3^{\text {rd }}$ harvest \\
\hline $\mathrm{G}^{\mathrm{a}}$ & $50.06 \mathrm{a}$ & $49.93 a$ & $50.50 \mathrm{a}$ & $37.85 b$ & $41.89 \mathrm{a}$ & $42.77 \mathrm{a}$ & $10.56 \mathrm{a}$ & $10.65 \mathrm{a}$ & $11.97 \mathrm{a}$ \\
\hline $\mathrm{G}+\mathrm{CGS}^{\mathrm{b}}$ & $42.86 \mathrm{~b}$ & $47.08 \mathrm{ab}$ & $53.72 \mathrm{a}$ & $38.94 \mathrm{a}$ & $42.39 \mathrm{a}$ & $42.37 \mathrm{a}$ & $11.19 \mathrm{a}$ & $10.24 \mathrm{a}$ & $10.93 \mathrm{a}$ \\
\hline $\mathrm{G}+\mathrm{MS}^{\mathrm{c}}$ & $34.30 \mathrm{~b}$ & $46.24 \mathrm{a}$ & $51.39 \mathrm{a}$ & $42.40 \mathrm{a}$ & $42.82 \mathrm{a}$ & $43.20 \mathrm{a}$ & $10.60 \mathrm{a}$ & $10.33 \mathrm{a}$ & $12.32 \mathrm{a}$ \\
\hline $\mathrm{G}+\mathrm{AB}^{\mathrm{d}}$ & $44.92 \mathrm{a}$ & $49.52 \mathrm{a}$ & $47.22 \mathrm{a}$ & $36.86 \mathrm{~b}$ & $41.45 \mathrm{a}$ & $41.08 \mathrm{a}$ & $11.14 \mathrm{a}$ & $9.92 \mathrm{a}$ & $11.28 \mathrm{a}$ \\
\hline $\mathrm{G}+\mathrm{AA}^{\mathrm{e}}$ & $47.45 \mathrm{a}$ & $42.96 \mathrm{a}$ & $50.53 \mathrm{a}$ & $37.44 \mathrm{~b}$ & $41.63 \mathrm{a}$ & $42.25 \mathrm{a}$ & $12.25 \mathrm{a}$ & $10.27 \mathrm{a}$ & $12.28 \mathrm{a}$ \\
\hline
\end{tabular}

Note. Means followed by the same letter do not differ at the $5 \%$ probability level according to the Tukey test, which compares the forages among the harvests.

Table 6. NDF, ADF and lignin (\%) contents of leguminous plants intercropped with Coastcross grass.

\begin{tabular}{|c|c|c|c|c|c|c|c|c|c|}
\hline \multirow{2}{*}{ Leguminous } & \multicolumn{3}{|c|}{ Values of NDF } & \multicolumn{3}{|c|}{ Values of ADF } & \multicolumn{3}{|c|}{ Values of lignin (\%) } \\
\hline & $1^{\text {st }}$ harvest & $2^{\text {nd }}$ harvest & $3^{\text {rd }}$ harvest & $1^{\text {st }}$ harvest & $2^{\text {nd }}$ harvest & $3^{\text {rd }}$ harvest & $1^{\text {st }}$ harvest & $2^{\text {nd }}$ harvest & $3^{\text {rd }}$ harvest \\
\hline $\mathrm{CGS}^{\mathrm{a}}$ & $40.86 \mathrm{~b}$ & $37.71 \mathrm{~b}$ & $62.18 \mathrm{a}$ & $40.80 \mathrm{~b}$ & $44.27 \mathrm{~b}$ & $47.92 \mathrm{a}$ & $11.85 \mathrm{a}$ & $11.37 \mathrm{a}$ & $11.31 \mathrm{a}$ \\
\hline$M S^{b}$ & $29.99 b$ & $37.08 \mathrm{~b}$ & $62.63 \mathrm{a}$ & $39.91 b$ & $41.29 b$ & $45.91 \mathrm{a}$ & $13.81 \mathrm{a}$ & $12.89 \mathrm{a}$ & $15.17 \mathrm{a}$ \\
\hline $\mathrm{AB}^{\mathrm{c}}$ & $34.84 \mathrm{~b}$ & $29.22 b$ & $66.90 \mathrm{a}$ & $38.15 \mathrm{a}$ & $37.86 \mathrm{a}$ & $40.45 a$ & $13.94 \mathrm{a}$ & $12.51 \mathrm{a}$ & $14.12 \mathrm{a}$ \\
\hline $\mathrm{AA}^{\mathrm{d}}$ & $37.47 \mathrm{~b}$ & $37.02 \mathrm{~b}$ & $65.47 \mathrm{a}$ & $30.64 \mathrm{~b}$ & $36.09 \mathrm{a}$ & $37.59 \mathrm{a}$ & $12.26 \mathrm{~b}$ & $13.33 \mathrm{~b}$ & $16.96 \mathrm{a}$ \\
\hline
\end{tabular}

Note. See caption Table 5.

The NDF content was higher in grasses compared to legumes in the first and second harvests. An increase occurred over the course of the harvesting periods for mono- and intercropped G. The grass showed no difference from the intercropped plant within harvests, possibly indicating that the presence of the legume does not affect the production of structural carbohydrates. Statistically, the effect of fertilisation was insignificant.

An effect $(\mathrm{p}<0.05)$ of harvest time on the NDF content of the legumes was detected, and this content increased over time (harvests). The forage with the lowest NDF content was AA. No effect $(p>0.05)$ of fertilisation was observed on the evaluated parameters. 
The literature shows that factors such as species, climate (water, light and temperature), soil fertility, maturity, harvest and animal management can affect the chemical composition and, consequently, the energy content of food. In addition, the availability of old forage for grazing can increase dry mass yield but decrease the chemical quality by increasing the proportion of cell wall (cellulose, hemicellulose and lignin) relative to content (Elgersma \& Søegaard, 2018).

The consumption of diets with a high NDF content implies lower levels of net energy for cattle and a slow rate of degradation and passage, which limits intake due to rumen filling. Diets with a high NDF content decrease the efficiency of rumination and mastication because of the difficulty in reducing the particle size of fibre-rich materials, thereby reducing food intake (Owens \& Basalan, 2016). The NDF values were $73.02 \%$ for $\mathrm{G}$ and $54.03 \%$ for AA. These values are close to those found by Paris et al. (2008), $74.6 \%$ for G and $52.8 \%$ A pintoi, when studying the NDF, in different strata of intercropped pastures, with and without $\mathrm{N}$ fertilisation. The findings of the present study show the $A$. pinto $i$ legume to be a good food source for cattle.

A significant effect $(p<0.05)$ of harvest time existed for monocropped $G$ and $G$ intercropped with AB and AA (Table 5), with an increase in the ADF content as the plant aged. The ADF content in the intercropped grass did not differ from that of the monocropped grass $(\mathrm{p}>0.05)$, possibly indicating that the intercropping did not affect fibre production. Statistically, the effect of fertilisation was insignificant.

A significant effect $(\mathrm{p}<0.05)$ of harvest time did exist for the ADF content of legumes, with an increase in ADF content for the CGS, MS and AA legumes. The effect of fertilisation was not statistically significant $(p>0.05)$.

The increase over the course of the harvests indicates a reduction of cellular content and an increase in fibre content, causing a decrease in the nutritive value of forage plants (Bumb et al., 2016). The legume AB was the only cultivar in this study that did not present a significant difference $(p<0.05)$ in the ADF content over the three harvests.

In general, an increase in lignin content occurred with plant maturity for the mono- and intercropped G; however, this effect was not statistically significant (Table 5). The lignin content of the intercropped grass did not differ significantly from that of the monocropped grass $(p>0.05)$. The effect of fertilisation was not significant $(p>$ $0.05)$.

Regarding the legumes, the harvest time influenced $(\mathrm{p}<0.05)$ the lignin content of the AA legume. The legumes had a higher lignin content than that found in the mono- and intercropped G.

Legumes have higher lignin contents than those of grasses due to the higher concentration of hemicellulose in grasses. However, as lignin binds covalently to hemicellulose, its effect on digestibility may be more damaging in grass than in legumes (Tian et al, 2019). The CGS legume showed the lowest lignin content in the present study (Table 6). Costa et al. (2016) found a relatively high lignin content of 25.4 and $23.3 \%$, respectively, for the Mineirão and Campo Grande cultivars of S. guianensis.

The fibrous constituents (NDF, ADF and lignin) strongly affect the quality of animal diet and correlate negatively with digestibility because of their role in protecting the cellular contents and supporting the plant structures. Therefore, these constituents increase with the age, making forage intake and digestibility increasingly difficult (Tian et al., 2019).

\subsection{Quantification of Condensed Tannins}

The data related to the condensed tannin content of G (mono- and intercropped) and the legumes for the three harvests are recorded in Table 7. 
Table 7. Condensed tannin $\left(\mu \mathrm{g} \mathrm{mL}^{-1}\right)$ content of monocropped grass and intercropped grass and legumes compared among harvests, with and without fertilisation

\begin{tabular}{|c|c|c|c|c|c|c|}
\hline \multirow{2}{*}{ Forages } & \multicolumn{3}{|c|}{ Fertilised } & \multicolumn{3}{|c|}{ Non Fertilised } \\
\hline & $1^{\text {st }}$ harvest & $2^{\text {nd }}$ harvest & $3^{\text {rd }}$ harvest & $1^{\text {st }}$ harvest & $2^{\text {nd }}$ harvest & $3^{\text {rd }}$ harvest \\
\hline $\mathrm{G}$ & $0.00016 \mathrm{cB}$ & $0.00660 \mathrm{abA}$ & $0.00695 \mathrm{bcA}$ & $0.00636 \mathrm{bA}$ & $0.00014 \mathrm{aB}$ & $0.00690 \mathrm{bA}$ \\
\hline $\mathrm{G}+\mathrm{CGS}$ & $0.00020 \mathrm{cC}$ & $0.00677 \mathrm{abA}$ & $0.00706 \mathrm{bA}$ & $0.00489 \mathrm{cB}$ & $0.00028 \mathrm{aB}$ & $0.00668 \mathrm{bA}$ \\
\hline $\mathrm{G}+\mathrm{MS}$ & $0.00043 \mathrm{cB}$ & $0.00644 \mathrm{bA}$ & $0.00666 \mathrm{bcA}$ & $0.00015 \mathrm{eB}$ & $0.00037 \mathrm{aC}$ & $0.00334 \mathrm{~dB}$ \\
\hline $\mathrm{G}+\mathrm{AB}$ & $0.00017 \mathrm{cB}$ & $0.00657 \mathrm{bA}$ & $0.00659 \mathrm{bA}$ & $0.00019 \mathrm{eB}$ & $0.00015 \mathrm{aB}$ & $0.00662 \mathrm{bA}$ \\
\hline $\mathrm{G}+\mathrm{AA}$ & $0.00027 \mathrm{cB}$ & $0.00755 \mathrm{aA}$ & $0.00026 \mathrm{eB}$ & $0.00021 \mathrm{eB}$ & $0.00026 \mathrm{aB}$ & $0.01004 \mathrm{aA}$ \\
\hline CGS & $0.00045 \mathrm{cB}$ & $0.00347 \mathrm{aA}$ & $0.00584 \mathrm{cB}$ & $0.00382 \mathrm{dA}$ & $0.00024 \mathrm{aC}$ & $0.00694 \mathrm{bA}$ \\
\hline MS & $0.00928 \mathrm{aA}$ & $0.00533 \mathrm{cC}$ & $0.00663 \mathrm{bcA}$ & $0.00834 \mathrm{aB}$ & $0.00021 \mathrm{aC}$ & $0.00351 \mathrm{cdB}$ \\
\hline $\mathrm{AB}$ & $0.00364 \mathrm{bC}$ & $0.00513 \mathrm{cdB}$ & $0.00308 \mathrm{~dB}$ & $0.00721 \mathrm{bA}$ & $0.00041 \mathrm{aC}$ & $0.00438 \mathrm{cA}$ \\
\hline AA & $0.00929 \mathrm{aA}$ & $0.00436 \mathrm{deC}$ & $0.00928 \mathrm{aA}$ & $0.00712 \mathrm{bB}$ & $0.00026 \mathrm{aC}$ & $0.00369 \mathrm{cdB}$ \\
\hline
\end{tabular}

Note. Means followed by the same lowercase letter and capital letter do not differ at the $5 \%$ probability level according to the Tukey test.

A significant effect $(p<0.05)$ of harvest season on the phenolic compounds occurred for the mono- and intercropped grasses and for both the fertilised and non-fertilised legumes (Table 7). In general, the content of condensed tannin increased for the mono- and intercropped $G$ but did not differ among the legumes $(p>0.05)$. Among the legumes, the condensed tannins increased from the first to the third harvest for the CGS cultivar. The MS, AB and AA cultivars showed a decrease, whereas the AB cultivar showed an increase in the second harvest and a decrease in the third. The fertilisation treatment affected most of the species $(\mathrm{p}<0.05)$ and was noticeable in comparisons of the condensed tannin concentrations between the first and the second harvests. Although all the values (fertilised or not) showed statistically significant differences, a greater concentration increase occurred for the fertilised species.

Phenolic compounds have antioxidant capacity and can therefore play a significant role in reducing the risk of cardiovascular diseases and some cancers. However, in diets for monogastric animal species, tannins may reduce the digestibility of proteins, carbohydrates and minerals; decrease the activity of digestive enzymes; and damage the mucosa of the digestive system (Thakur, Sharma, \& Thakur, 2019). Condensed tannins are considered antinutritional when they occur in DM concentrations above $5 \times 10^{7} \mu \mathrm{g} \mathrm{kg}^{-1}$, at this concentration, these tannins reduce forage palatability and, consequently, DM intake and digestibility (Saminathan et al., 2015).

The legumes had higher levels of condensed tannins, and the association of cattle with grass increases this content in their diet, which may have an undesirable effect on palatability and forage digestibility. However, depending on the nature and concentration of these tannins in the forage, some advantages can be obtained, especially with protein-rich diets. The use of species such as Leucaena, whose concentrations of condensed tannins are high, has led to reduced methane emissions by cattle. In addition, legumes containing condensed tannins are termed "non-tympanic" because of their reactivity in forming complexes with proteins, thereby preventing foaming in the rumen and improving protein absorption in the small intestine (Chini et al., 2016).

\subsection{Separation and Identification of Phenolic Compound Patterns by HPLC}

The methodology for separating the phenolic components present in the samples was optimised and validated by obtaining the retention time, retention factor $\left(\mathrm{k}^{\prime}\right)$, resolution, limits of quantification (LOQs), LODs, interval of linearity and coefficient of determination for each of the standard compounds (Table 8). 
Table 8. Chromatographic parameters of the phenolic standards analysed using the developed HPLC system

\begin{tabular}{|c|c|c|c|c|c|c|c|c|}
\hline Analyte (peak number) ${ }^{a}$ & $\begin{array}{l}\text { Retention } \\
\text { time (min) }\end{array}$ & $\begin{array}{l}\text { Retention } \\
\text { factor } k^{\prime}\end{array}$ & Resolution & $\begin{array}{l}\text { LOD } \\
\left(\mathrm{mg} \mathrm{L}^{-1}\right)\end{array}$ & $\begin{array}{l}\text { LOQ } \\
\left(\mathrm{mg} \mathrm{L}^{-1}\right)\end{array}$ & $\begin{array}{l}\text { Linearity range } \\
\left(\mathrm{mg} \mathrm{L}^{-1}\right)\end{array}$ & Linear regression equation & $\begin{array}{l}\text { Coefficient of } \\
\text { determination }\end{array}$ \\
\hline Gallic acid (1) & 13.72 & 7.81 & & 0.10 & 0.30 & $0.27-9.27$ & $y=-5898.66+27102.64 x$ & 0.9995 \\
\hline Gallocatechin (2) & 18.87 & 10.9 & 6.02 & 0.80 & 2.30 & $1.53-39.47$ & $y=-2388.24+8732.46 x$ & 0.9990 \\
\hline Epigallocatechin gallate (3) & 25.23 & 11.7 & 10.2 & 0.18 & 0.80 & $0.64-24.29$ & $y=2202.21+3289.93 x$ & 0.9992 \\
\hline Catechin (4) & 25.71 & 12.9 & 1.20 & 0.09 & 0.17 & $0.46-15.52$ & $y=-4846.18+29944.23 x$ & 0.9995 \\
\hline Epicatechin (5) & 29.52 & 13.9 & 7.36 & 0.09 & 0.70 & $0.46-37.03$ & $y=19924.68+23638.63 x$ & 0.9997 \\
\hline Caffeic acid (6) & 30.48 & 15.3 & 1.80 & 0.05 & 0.84 & $0.48-28.83$ & $y=-65593.05+149762.57 x$ & 0.9995 \\
\hline Vanillin (7) & 31.68 & 16.5 & 1.99 & 0.02 & 0.07 & $0.05-11.3$ & $y=-703.36+254010.86 x$ & 0.9994 \\
\hline p-Coumaric acid (8) & 34.44 & 16.8 & 2.79 & 0.05 & 0.54 & $0.26-26.92$ & $y=-12019.34+71995.03 x$ & 0.9998 \\
\hline Ferulic acid (9) & 34.66 & 17.2 & 0.20 & 0.02 & 0.08 & $0.05-16.17$ & $y=-40744.15+219048.45 x$ & 0.9991 \\
\hline$m$-Coumaric acid (10) & 36.65 & 17.5 & 1.29 & 0.02 & 0.15 & $0.08-18.82$ & $y=-139606.67+415600.59 x$ & 0.9991 \\
\hline$o$-Coumaric acid (11) & 38.99 & 18.3 & 3.13 & 0.02 & 0.17 & $0.07-13.67$ & $y=22484.41+224614.45 x$ & 0.9994 \\
\hline Ellagic acid (12) & 40.10 & 18.7 & 1.33 & 0.27 & 0.54 & $0.48-25.98$ & $y=-29225.81+36559.71 x$ & 0.9994 \\
\hline Quercetin (13) & 50.04 & 19.2 & 8.86 & 0.20 & 0.80 & $0.40-42.48$ & $y=40450.13+16281.02 x$ & 0.9991 \\
\hline
\end{tabular}

The LODs and LOQs of the phenolic standards ranged from 0.02 to $0.8 \mathrm{mg} \mathrm{L}^{-1}$ and 0.07 to $2.30 \mathrm{mg} \mathrm{L}^{-1}$, respectively. Calibration curves constructed between 0.05 and $42.48 \mathrm{mg} \mathrm{L}^{-1}$ showed strong linear correlations between the concentration and the peak area, with coefficient of determination $>0.999$ for all the phenolic standards. The accuracy of the analytical method, as determined by the three consecutive measurements of the standard compounds, showed mean standard deviations ranging from 0.001 to $6.83 \%$. These data indicate an acceptable accuracy for validation when the deviation is less than $20 \%$.

The recovery measures were also performed for each compound analysed in order to verify the accuracy of the applied methodology (Table 9).

Table 9. Recovery of phenolic compounds from forage samples after addition of known concentration of standards

\begin{tabular}{|c|c|c|c|c|}
\hline Analyte (peak number) ${ }^{a}$ & $\begin{array}{l}\text { Concentration in } \\
\text { sample }\left(\mathrm{mg} \mathrm{L}^{-1}\right)\end{array}$ & $\begin{array}{l}\text { Concentration of } \\
\text { standard added }\left(\mathrm{mg} \mathrm{L}^{-1}\right)\end{array}$ & $\begin{array}{l}\text { Measured concentration } \\
\text { of mixture }\left(\mathrm{mg} \mathrm{L}^{-1}\right)\end{array}$ & Recovery (\%) \\
\hline Gallic acid (1) & 0.011 & 0.85 & 0.84 & 98.82 \\
\hline Gallocatechin (2) & 0.150 & 2.29 & 2.24 & 97.82 \\
\hline Epigallocatechin gallate (3) & $<\mathrm{DL}^{\mathrm{b}}$ & 1.45 & 1.45 & 100 \\
\hline Catechin (4) & 0.243 & 1.45 & 1.60 & 92.34 \\
\hline Epicatechin (5) & 0.056 & 0.90 & 0.93 & 93.33 \\
\hline Caffeic acid (6) & 0.093 & 0.76 & 0.84 & 98.53 \\
\hline Vanillin (7) & 0.162 & 0.82 & 0.93 & 95.41 \\
\hline$p$-Coumaric acid (8) & 0.015 & 0.97 & 0.91 & 93.81 \\
\hline Ferulic acid (9) & 0.023 & 0.82 & 0.83 & 97.22 \\
\hline$m$-Coumaric acid (10) & 0.021 & 0.82 & 0.80 & 97.56 \\
\hline$o$-Coumaric acid (11) & 0.069 & 1.51 & 1.50 & 99.34 \\
\hline Ellagic acid (12) & $<\mathrm{DL}$ & 1.69 & 1.69 & 100 \\
\hline Quercetin (13) & $<\mathrm{DL}$ & 1.53 & 1.53 & 100 \\
\hline
\end{tabular}

Note. ${ }^{\mathrm{a}}$ Numbers correspond to peaks shown in Figure $1 ;{ }^{\mathrm{b}}<\mathrm{DL}:<$ detection limit.

The recovery percentages, determined by the standard addition method, ranged from 92.34 to $100 \%$. Good recovery of the analytes indicates that no significant degradation or loss of the compounds occurred while applying the methodology.

Figure 1 shows the chromatographic profile of the caffeic, $(p, m$ and $o$ )-coumaric, gallic, ellagic and ferulic phenolic acids as well as the catechin, epicatechin, gallocatechin, and epigallocatechin gallate tannins and the quercetin and vanillin flavonoids. 


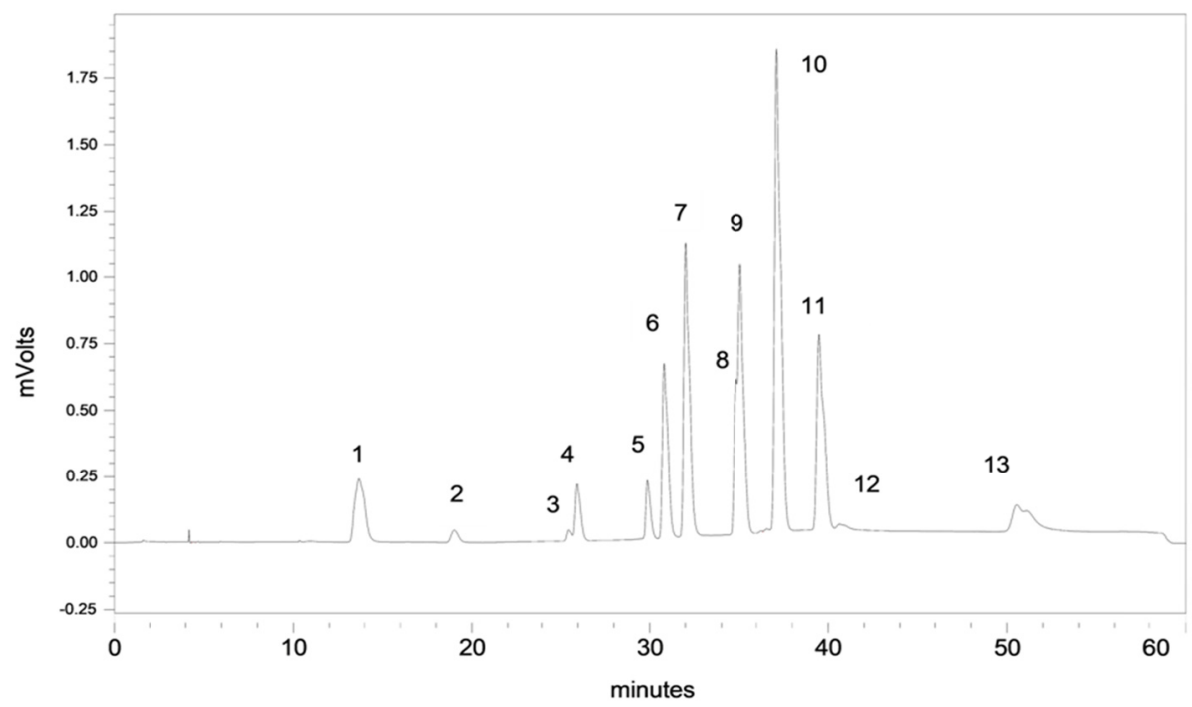

Figure 1. HPLC chromatogram of standard phenolic compounds detected at $280 \mathrm{~nm}$. Key to peak identity: 1) gallic acid; 2) gallocatechin; 3) epigallocatechin gallate; 4) catechin; 5) epicatechin; 6) caffeic acid; 7) vanillin; 8) $p$-coumaric acid; 9) ferulic acid; 10) $m$-coumaric acid; 11) $o$-coumaric acid; 12) ellagic acid; 13) quercetin. (For chromatographic conditions, see Materials and methods)

\subsection{Concentration of the Phenolic Compounds in Forages}

The following compounds were evaluated (Table 10): the ferulic and ( $p, m$ and $o$ )-coumaric phenolic acids; the acids derived from caffeic, gallic and ellagic hydrolysable tannins; the condensed tannin monomers catechin, epicatechin, gallocatechin and epigallocatechin gallate; and the quercetin and vanillin flavonoids.

Table 10. Concentration of the phenolic compounds $\left(\mu \mathrm{g} \mathrm{mg}^{-1}\right)$, observing the interaction between forages and fertilisation

\begin{tabular}{|c|c|c|c|c|c|c|c|c|c|c|}
\hline \multirow{2}{*}{ Phenoloids } & \multicolumn{2}{|c|}{ Coastcross-1 } & \multicolumn{2}{|c|}{ Campo Grande stylo } & \multicolumn{2}{|c|}{ Mineirão stylo } & \multicolumn{2}{|c|}{ Amarillo pinto peanut } & \multicolumn{2}{|c|}{ Belmonte pinto peanut } \\
\hline & $\mathbf{A}$ & NA & A & NA & $\mathbf{A}$ & NA & $\mathbf{A}$ & NA & $\mathbf{A}$ & NA \\
\hline Gallic acid & $<\mathrm{DL}$ & $<\mathrm{DL}$ & $0.027 \pm 0.000$ & $<\mathrm{DL}$ & $<\mathrm{DL}$ & $<\mathrm{DL}$ & $<\mathrm{DL}$ & $0.076 \pm 0.021$ & $0.012 \pm 0.000$ & $<\mathrm{DL}$ \\
\hline Gallocatechin & $<\mathrm{DL}$ & $<\mathrm{DL}$ & $0.0179 \pm 0.005$ & $<\mathrm{DL}$ & $0.029 \pm 0.000$ & $0.012 \pm 0.000$ & $<$ DL & $<$ DL & $<\mathrm{DL}$ & $<\mathrm{DL}$ \\
\hline $\begin{array}{l}\text { Epigallocatechin } \\
\text { gallate }\end{array}$ & $0.044 \pm 0.002$ & $0.037 \pm 0.002$ & $<\mathrm{DL}$ & $<\mathrm{DL}$ & $<$ DL & $<\mathrm{DL}$ & $<\mathrm{DL}$ & $<\mathrm{DL}$ & $<\mathrm{DL}$ & $<\mathrm{DL}$ \\
\hline Catechin & $0.0071 \pm 0.003$ & $0.0044 \pm 0.003$ & $<\mathrm{DL}$ & $<\mathrm{DL}$ & $<\mathrm{DL}$ & $<\mathrm{DL}$ & $<\mathrm{DL}$ & $<\mathrm{DL}$ & $<\mathrm{DL}$ & $<\mathrm{DL}$ \\
\hline Epicatechin & $0.043 \pm 0.045$ & $0.022 \pm 0.023$ & $0.061 \pm 0.000$ & $0.033 \pm 0.003$ & $0.065 \pm 0.004$ & $0.049 \pm 0.005$ & $<\mathrm{DL}$ & $<\mathrm{DL}$ & $0.054 \pm 0.026$ & $0.069 \pm 0.000$ \\
\hline Caffeic acid & $0.013 \pm 0.008$ & $0.0013 \pm 0.000$ & $0.008 \pm 0.000$ & $0.020 \pm 0.007$ & $0.009 \pm 0.000$ & $0.010 \pm 0.003$ & $0.015 \pm 0.000$ & $0.025 \pm 0.007$ & $0.036 \pm 0.022$ & $0.020 \pm 0.004$ \\
\hline Vanillin & $0.006 \pm 0.006$ & $0.008 \pm 0.007$ & $0.003 \pm 0.000$ & $0.003 \pm 0.000$ & $0.010 \pm 0.010$ & $0.004 \pm 0.003$ & $0.007 \pm 0.000$ & $<$ DL & $0.024 \pm 0.000$ & $0.005 \pm 0.000$ \\
\hline$p$-Coumaric acid & $0.009 \pm 0.005$ & $0.029 \pm 0.015$ & $0.026 \pm 0.012$ & $<\mathrm{DL}$ & $0.018 \pm 0.001$ & $0.019 \pm 0.004$ & $<$ DL & $<\mathrm{DL}$ & $0.040 \pm 0.000$ & $0.024 \pm 0.004$ \\
\hline Ferulic acid & $0.004 \pm 0.002$ & $0.007 \pm 0.000$ & $0.004 \pm 0.000$ & $0.007 \pm 0.000$ & $0.004 \pm 0.000$ & $0.003 \pm 0.000$ & $<$ DL & $0.025 \pm 0.011$ & $0.017 \pm 0.000$ & $<\mathrm{DL}$ \\
\hline$m$-Coumaric acid & $0.003 \pm 0.000$ & $0.004 \pm 0.000$ & $0.009 \pm 0.002$ & $0.007 \pm 0.000$ & $0.015 \pm 0.000$ & $0.008 \pm 0.003$ & $0.009 \pm 0.005$ & $<\mathrm{DL}$ & $0.008 \pm 0.003$ & $0.004 \pm 0.002$ \\
\hline$o$-Coumaric acid & $<\mathrm{DL}$ & $0.005 \pm 0.004$ & $0.011 \pm 0.000$ & $<\mathrm{DL}$ & $0.030 \pm 0.001$ & $<\mathrm{DL}$ & $0.006 \pm 0.000$ & $<\mathrm{DL}$ & $0.009 \pm 0.000$ & $0.008 \pm 0.002$ \\
\hline Ellagic acid & $0.009 \pm 0.006$ & $0.011 \pm 0.000$ & $<\mathrm{DL}$ & $<\mathrm{DL}$ & $<\mathrm{DL}$ & $<\mathrm{DL}$ & $0.060 \pm 0.002$ & $<\mathrm{DL}$ & $<\mathrm{DL}$ & $<\mathrm{DL}$ \\
\hline Quercetin & $<$ DL & $<\mathrm{DL}$ & $0.028 \pm 0.000$ & $<$ DL & $<\mathrm{DL}$ & $<$ DL & $<$ DL & $0.076 \pm 0.021$ & $0.013 \pm 0.000$ & $<\mathrm{DL}$ \\
\hline
\end{tabular}

Note. Compounds that could not be quantified in the samples are labelled $<$ DL.

Some studies have reported that the presence of phenolic compounds is directly related to allelopathic activity, which may cause growth inhibition and even germination inhibition in other species belonging to the same taxon. As an example, gallic, caffeic and ellagic acids act as allelopathic and germination-inhibiting substances in a large number of plants (Fiorenza et al., 2016).

A polyphenolic nature and a high molecular weight are structural characteristics that give certain condensed tannins, such as catechins and the gallocatechin and epigallocatechin isomers, physicochemical properties that include the capacity to form insoluble complexes with proteins, the complexation of certain metal ions, a high reducing power and the ability to neutralise oxygen-free radicals. These properties are responsible for important 
biological effects, such as antitumour, antibacterial, antiviral, anti-inflammatory, vasoprotective, enzyme inhibitor (phospholipase A2, cyclooxygenase, lipoxygenase glutathione reductase and xanthine oxidase), anti-allergic and especially antioxidant activity (Yahfoufi et al., 2018).

Epigallocatechin gallate, catechin, epicatechin, caffeic acid, ellagic acid, $p$ - and $m$-coumaric acids, ferulic acid and the flavonoid vanillin were identified in G (Table 10). These compounds were present in both the fertilised and non-fertilised cases. $o$-Coumaric acid was only present in the non-fertilised grass. $G$ was the grass cropping system with the largest variety of phenolic compounds. This observation may be related to the higher $\mathrm{G}$ resistance to wind, disease and defoliation compared to that of legumes (Ruckle et al., 2017). The following compounds were identified in the CGS cultivar: gallocatechin and epicatechin; caffeic, gallic, $p$-coumaric, $o$-coumaric, $m$-coumaric and ferulic acids; and the flavonoids vanillin and quercetin. These compounds were present mostly in fertilised species. Thus, fertilisation can be considered to have influenced the presence of these compounds in this legume.

In the MS cultivar, gallocatechin and epicatechin; caffeic, $p$-coumaric, $o$-coumaric, $m$-coumaric and ferulic acids; and the flavonoid vanillin were identified. Both the fertilised and non-fertilised plants contained these compounds, except for $o$-coumaric acid which appeared only in the fertilised plants.

In the AA plants, the following few phenolic compounds were detected: caffeic, gallic, ellagic, $o$-coumaric, $\mathrm{m}$-coumaric and ferulic acids and the flavonoids vanillin and quercetin. No pattern existed to suggest more compounds in the fertilised or non-fertilised plants.

In $\mathrm{AB}$, epicatechin and caffeic and gallic acids were detected. The occurrence of the $o$-coumaric, $m$-coumaric, $p$-coumaric and ferulic organic acids and the flavonoids vanillin and quercetin was observed. Most of the compounds were present in fertilised plants, which contained higher concentrations when compared to the non-fertilised plants.

Caffeic acid was the only compound detected in all the cultivars. This compound is not only a hydrolysis product of tannins but also a derivative of cinnamic acid and is directly involved in the association of lignin with cell wall hemicelluloses. Forages show significant lignin deposition, which may relate to the occurrence of caffeic acid in the cultivars. In general, $p$-coumaric acid has a strongly negative effect on the digestibility of forages, and this acid is considered highly toxic to rumen microorganisms. This acid was absent only in AA, which may contribute to a better digestibility of this cultivar in relation to the other cultivars analysed (Ruckle et al., 2017).

The amount and type of tannin in plants varies according to the plant species, and genetic differences are possible in the same species (Jugran et al., 2016). This variation can also occur with the cultivar, the tissue, the stage of development and the environmental conditions in which the plants are found.

The literature contains studies that used HPLC to identify tannins, or their derivatives, in forages of several species. Gallic acid was detected in forage legume Sulla carnosa (Hafsi et al., 2016). The gallic, ellagic, caffeic, catechin, epicatechin, gallocatechin and epigallocatechin acids were identified in Onobrychis viciifolia Cotswold Common variety (Regos, Urbanella, \& Treutter, 2009). Epigallocatechin, catechin, epicatechin and gallocatechin were identified in Purple Prairie Clover (Dalea purpurea Vent.) (Peng et al., 2018).

The groups of phenolic compounds most abundant in foods are flavonoids, phenolic acids and lignins. Phenolic acids belong to a class of secondary metabolites that are widely distributed in plants. In forages, the presence of phenolic acids is restricted to the cell wall, and digestibility has been related to the amount of these acids present in the different tissues (Raffrenato et al., 2017).

The literature also references the quantification and identification of these acids by HPLC. Kuppusamy et al. (2018) identified and quantified by LC-MS different phenolic acids, including caffeic acid, ferulic acid, $p$-coumaric acid, chlorogenic acid, dihydroxy benzoic acid, propyl gallate, catechin, and six flavonoids from Italian ryegrass extract. In the present study, Italian ryegrass silage powder was extracted with ethanol: water for $20 \mathrm{~min}$ at $90{ }^{\circ} \mathrm{C}$. The extract targeted optimum yield of phenolic acids and flavonoids. Crude phenolic acid and flavonoids were then purified by solid phase extraction method. Purified fractions were then injected into HPLC with a diode-array detector. Quantified concentrations of isolated phenolic acids and flavonoids ranged from 125 to $220 \mu \mathrm{g} \mathrm{g}^{-1}$ dry weight. Limits of detection and limits of quantification for all standards (unknown compounds) ranged from 0.38 to 1.71 and 0.48 to $5.19 \mu \mathrm{g} \mathrm{g}^{-1}$ dry weight, respectively.

\section{Conclusion}

The results of the chemical composition analysis showed that the AA legume presented the best results for the $\mathrm{Ca}$ and $\mathrm{P}$ contents and had an adequate $\mathrm{CP}$ content and the lowest NDF level, indicating that this cultivar possesses good nutritive value. The content of condensed tannins was higher in legumes than in grass, which may indicate that the association with grass increases the condensed tannin content of the animal diet and may cause an 
undesirable effect on forage palatability and digestibility. However, as the analysed legumes to have high protein content, these antinutritional factors can be minimised. Grass $\mathrm{G}$ was the forage with the greatest variety of detected phenolic compounds, probably due to the greater resistance of this cultivar to wind, disease and defoliation compared to legumes. The AA cultivar was the most interesting alternative for intercropping with G.

\section{Acknowledgements}

This study was financed by the Coordenação de Aperfeiçoamento de Pessoal de Nível Superior - Brasil (CAPES) Finance Code 001. We are thankful to CAPES for the scholarships and financial supports to CNPq and FAPEMIG for financial support.

\section{References}

Agostini-Costa, T. S., Lima, A., \& Lima, M. V. (2003). Determinação de Tanino em pedúnculo de caju: método da vanilina versus método do butanol ácido. Química Nova, 26, 763-765. https://doi.org/10.1590/ S0100-40422003000500022

Aguirre, P. F., Olivo, C. J., Smonetti, G. D., Agnolin, C. A., Nunes, J. S., De Bem, C. M., ... Fernandes, P. R. (2016). Valor nutritivo de pastagens de Coastcross-1 em consórcio com diferentes leguminosas de ciclo hibernal. Arquivo Brasileiro de Medicina Veterinária e Zootecnia, 68(1), 173-181. https://doi.org/10.1590/ $1678-4162-7314$

AOAC (Association of Official Analytical Chemists). (2005) Official Methods of Analysis (18th ed.). Gaithersburg, Maryland.

Aquino, F. W. B., Nascimento, R. F., Rodrigues, S., \& Casemiro, A. R. S. (2006). Determinação de marcadores de envelhecimento em cachaças. Ciência e Tecnologia de Alimentos, 26(1), 145-149. https://doi.org/ 10.1590/S0101-20612006000100024

Bumb, I., Garnier, E., Bastianelli, D., Richarte, J., Bonnal, L., \& Kazakou, E. (2016). Influence of management regime and harvest date on the forage quality of rangelands plants: the importance of dry matter content. AoB PLANTS, 8, 15. https://doi.org/10.1093/aobpla/plw045

Chini, S. O., Escosteguy, P. A. V., Scheffer-Basso, S. M., Sobottka, A. M., Bertol, C. D., \& Dall'Agnol, M. (2016). Procyanidins in Lotus L. genotypes grown in soil with different saturations of aluminum. Ciências Agrárias, 37(1), 85-94. https://doi.org/10.5433/1679-0359.2016v37n1p85

Costa, M. L. L., Rezende, A. S. C., Lana, A. M. Q., Santiago, J. M., Saliba, E. O. S., Silva, V. P., ... Moreira, D. C. A. (2016). Influence of storage on the chemical composition of Stylosanthes hays for equine feeding. Semina: Ciências Agrárias, 37(2), 903-910. https://doi.org/10.5433/1679-0359.2016v37n2p903

Elgersma, A., \& Søegaard, K. (2018). Changes in nutritive value and herbage yield during extended growth intervals in grass-legume mixtures: effects of species, maturity at harvest, and relationships between productivity and components of feed quality. Grass and Forage Science, 73(1), 78-93. https://doi.org/ $10.1111 /$ gfs. 12287

Figueiredo, R., Araújo, P., Llerena, J. P. P., \& Mazzafera, P. (2019). Suberin and hemicellulose in sugarcane cell wall architecture and crop digestibility: A biotechnological perspective. Food and Energy Security, 8, 1-24. https://doi.org/10.1002/fes3.163

Fiorenza, M., Dotto, D. B., Boligon, A. A., Boligon, A. A., Athayde, M. L., \& Vestena, S. (2016). Análise fitoquímica e atividade alelopática de extratos de Eragrostis plana Nees (capim-annoni). Iheringia, Série Botânica, Porto Alegre, 71(2), 193-200.

Gulwa, U., Mgujulwa, N., \& Beyene, S. T. (2017). Effect of Grass-legume intercropping on Dry Matter Yield and Nutritive Value of Pastures in the Eastern Cape Province, South Africa. Universal Journal of Agricultural Research, 5(6), 355-362. https://doi.org/10.13189/ujar.2017.050607

Hafsi, C., Falleh, H., Saada, M., Rabhi, M., Mkadmini, K., Ksouri, R., Abdelly, C., \& Smaoui, A. (2016). Effects of potassium supply on growth, gas exchange, phenolic composition, and related antioxidant properties in the forage legume Sulla carnosa. Flora, 223, 38-45. https://doi.org/10.1016/j.flora.2016.04.012

IUPAC (International Union of Pure and Applied Chemistry). (1997). Pure \& Appl. Chern. (Vol. 69, No. 2).

Jugran, A. K., Bahukhandi, A., Dhyani, P., Bhatt, I. D., Rawal, R. S., \& Nandi, S. K. (2016). Impact of Altitudes and Habitats on Valerenic Acid, Total Phenolics, Flavonoids, Tannins, and Antioxidant Activity of Valeriana jatamansi. Applied Biochemistry and Biotechnology, 179(6), 911-926. https://doi.org/10.1007/s12010016-2039-2 
Klabi, R., Bell, T. H., Hamel, C., Iwaasa, A., Schellenberg, M., Raies, A., \& St-Arnaud, M. (2015). Plant assemblage composition and soil $\mathrm{P}$ concentration differentially affect communities of AM and total fungi in a semi-arid grassland. FEMS Microbiology Ecology, 91, 1-13. https://doi.org/10.1093/femsec/fiu015

Kuppusamy, P., Lee, K. D., Song, C. E., Ilavenil, S., Srigopalram, S., Arasu, M. V., \& Choi, K. C. (2018). Quantification of major phenolic and flavonoid markers in forage crop Lolium multiflorum using HPLC-DAD. Revista Brasileira de Farmacognosia, 28(3), 282-288. https://doi.org/10.1016/j.bjp.2018. 03.006

Li, M., Zi, X., Zhou, H., Hou, G., \& Cai, Y. (2014). Chemical composition and in vitro digestibility of Stylosanthes guianensis varieties. Grassland Science, 60(2), 125-129. https://doi.org/10.1111/grs.12046

Machado, A. N., Siewerdt, L., Zonta, É. P., Vahl, L. C., Coelho, R. W., Ferreira, O. G. L., \& Affonso, A. B. (2005). Rendimento do amendoim-forrageiro estabelecido sob diferentes arranjos populacionais de plantas em Planossolo. Ciência Animal Brasileira, 6(3), 151-162.

Malavolta, E., Vitti, G. C., \& Oliveira, S. A. (1989). Avaliação do estado nutricional das plantas: Princípios e aplicações. Piracicaba: Associação Brasileira para Pesquisa da Potassa e do Fosfato.

Naumann, H. D., Tedeschi, L. O., Zeller, W. E., \& Huntley, N. F. (2017). The role of condensed tannins in ruminant animal production: Advances, limitations and future directions. Revista Brasileira de Zootecnia, 46(12), 929-949. https://doi.org/10.1590/s1806-92902017001200009

Olivo, C. J., Santos, J. C., Quatrin, M. P., Simonetti, G. D., Seibt, D. C., \& Diehl, M. S. (2016). Massa de forragem e valor nutritivo de pastagens de capim bermuda consorciadas com amendoim forrageiro ou ervilhaca. Acta Scientiarum. Animal Sciences, 38(3), 255-260.

Owens F. N., \& Basalan M. (2016). Ruminal Fermentation. In D. Millen, M. De Beni Arrigoni, R. Lauritano Pacheco (Eds.), Rumenology (pp. 63-102). Springer, Cham. https://doi.org/10.1007/978-3-319-30533-2_3

Paris, W., Cecato, U., Santos, G. T., Barbeiro, L., Avanzzo, L., \& Limão, V. (2008). Produção e qualidade de massa de forragem nos estratos da cultivar Coastcross-1 consorciada com Arachis pintoi com e sem adubação nitrogenada. Acta Scientiarum Animal Sciences, 30(2), 135-143. https://doi.org/10.4025/actasci animsci.v30i2.4676

Peng, K., Huang, Q., Xu, Z., McAllister, T. A., Acharya, S., Mueller-Harvey, I., ... Wang, Y. (2018). Characterization of Condensed Tannins from Purple Prairie Clover (Dalea purpurea Vent.) Conserved as either Freeze-Dried Forage, Sun-Cured Hay or Silage. Molecules, 23, 586. https://doi.org/10.3390/ molecules 23030586

Raffrenato, E., Fievisohn, R., Cotanch, K. W., Grant, R. J., Chase, L. E., \& Van Amburgh, M. E. (2017). Effect of lignin linkages with other plant cell wall components on in vitro and in vivo neutral detergent fiber digestibility and rate of digestion of grass forages. Journal of Dairy Science, 100(10), 8119-8131. https://doi.org/10.3168/jds.2016-12364

Regos, I., Urbanella, A., \& Treutter, D. (2009). Identification and Quantification of Phenolic Compounds from the Forage Legume Sainfoin (Onobrychis viciifolia). Journal of Agricultural and Food Chemistry, 57(13), 5843-5852. https://doi.org/10.1021/jf900625r

Ribani, M., Botolli, C. B. G., Collins, C. H., Jardim, I. C. S. F., \& Melo, L. F. C. (2004). Validação em métodos cromatográficos e eletroforéticos. Química Nova, 27(5), 771-780. https://doi.org/10.1590/S0100-4042200 4000500017

Ruckle, M., Meier, M., Frey, L., Eicke, S., Kölliker, R., Zeeman, S., \& Studer, B. (2017). Diurnal leaf starch content: an orphan trait in forage legumes. Agronomy, 7(1), 16. https://doi.org/10.3390/agronomy7010016

Saminathan, M., Sieo, C. C., Abdullah, N., Wong, C. M. V. L., \& Ho, Y. W. (2015). Effects of condensed tannin fractions of different molecular weights from a Leucaena leucocephala hybrid on in vitro methane production and rumen fermentation. Journal of the Science of Food and Agriculture, 95(13), 2742-2749. https://doi.org/10.1002/jsfa.7016

Terril, T. H., Windham, W. R., Evans, J. J., \& Hoveland, C. S. (1990). Condensed tannin concentration in Sericea Lespedeza as influenced by preservation method. Crop Science, 30, 219-224. https://doi.org/10.2135/ cropsci1990.0011183X003000010047x

Thakur, A., Sharma, V., \& Thakur, A. (2019). An overview of anti-nutritional factors in food. International Journal of Chemical Studies, 7(1), 2472-2479. 
Thorat, B. (2018). Chemical extraction and biomedical importance of secondary organic metabolites from plants-A review. Journal of Biomedical and Therapeutic Sciences, 5(1), 9-42.

Tian, Y., Zhang, X., Huang, R., \& Yu, P. (2019). Protein molecular structure, degradation and availability of canola, rapeseed and soybean meals in dairy cattle diets. Asian-Australasian Journal of Animal Sciences, 32(9), 1381-1388. https://doi.org/10.5713/ajas.18.0829

Van Soest, P. J. (1994). Nutritional ecology of the ruminant (2nd ed.). Ithaca, New York: Cornell University. https://doi.org/10.7591/9781501732355

Van Soest, P. J. (2018). Nutritional Ecology of the Ruminant (2nd ed.). Ithaca, NY: Cornell University Press.

Van Soest, P. J., Robertson, J. B., \& Lewis, B. A. (1991). Methods for dietary fiber, neutral detergent fiber, and nonstarch polysaccharides in relation to animal nutrition. Journal of Dairy Science, 74, 3583-3597. https://doi.org/10.3168/jds.S0022-0302 (91)78551-2

Yahfoufi, N., Alsadi, N., Jambi, M., \& Matar, C. (2018). The Immunomodulatory and Anti-Inflammatory Role of Polyphenols. Nutrients, 10(11), 1618. https://doi.org/10.3390/nu10111618

\section{Copyrights}

Copyright for this article is retained by the author(s), with first publication rights granted to the journal.

This is an open-access article distributed under the terms and conditions of the Creative Commons Attribution license (http://creativecommons.org/licenses/by/4.0/). 